Original Research Paper

\title{
Analysis of sea cucumber food habits (Holothuroidea) in Tanjung Gosale village Guraping subdistrict North Oba city Tidore Islands
}

\author{
Yuyun Abubakar $^{1 *}$ \& Fajria Dewi Salim ${ }^{1}$ \\ ${ }^{1}$ Program Studi Manajemen Sumberdaya Perairan Fakultas Perikanan dan Kelautan Universitas Khairun, \\ Indonesia
}

\author{
Article History \\ Received : September $10^{\text {th }}, 2021$ \\ Revised : September 20 ${ }^{\text {th }}, 2021$ \\ Accepted : September 30 3021 \\ Published : October $06^{\text {th }}, 2021$ \\ *Corresponding Author: \\ Yuyun Abubakar, \\ Program Studi Manajemen \\ Sumberdaya Perairan Fakultas \\ Perikanan dan Kelautan \\ Universitas Khairun, Ternate, \\ Indonesia; \\ Email: \\ daffayuyunabubakar@gmail.com
}

\begin{abstract}
This study aims to find out the composition of sea cucumber types in Tanjung Gosale Guraping Village, find out the composition of sea cucumber food types in Tanjung Gosale Guraping Village and determine the food habits of sea cucumber types (main food, supplements, and incidental foods) contained in the stomach contents of sea cucumbers. The research procedure is carried out measurements of the length and weight of sea cucumbers using a measuring bar and analytical scales. Then the sea cucumber is dissected to be taken by the stomach, then analyzed the food contained in the stomach. Before the stomach is dissected first done weighing the weight of the stomach using analytical scales and measurements of the length of the stomach using the bar. The stomach of sea cucumbers that have been surgically then carried out observations of the contents of the stomach per individual in a microscope to find out the types of food organisms contained in the stomach of the sea cucumber. The results showed that the composite.
\end{abstract}

Keywords: food habits; sea cucumber; Tanjung Gosale village.

\section{Pendahuluan}

Teripang (Holothuroidea) merupakan salah satu sumberdaya hayati laut yang potensial untuk dikembangkan karena memiliki nilai ekonomis penting dan kandungan gizi yang tinggi. Dalam dunia perdagangan internasional teripang dikenal dengan nama "Teat Fish" (Kordi, 2011). Teripang memiliki peran yang sangat penting baik secara ekonomi maupun ekologi. Secara ekonomi teripang dijadikan sebagai sumber makanan dan bahan dalam pembuatan kosmetika serta obat berbagai penyakit (Handayani et al., 2017)

Teripang merupakan golongan yang paling umum dijumpai. Hewan ini terdapat di paparan terumbu karang, pantai berbatu atau berlumpur, di laut dalam bahkan di palung laut. Martoyo et al., (2002), menyatakan bahwa dari hasil penelitian, kandungan nutrisi teripang dalam kondisi kering terdiri dari protein $0,2 \%$, lemak $1,7 \%$, kadar air $0,9 \%$, kadar abu $0,6 \%$ dan karbohidrat $4,8 \%$. Lebih lanjut dikatakan bahwa teripang dipasarkan dalam beberapa bentuk produk diantaranya beberapa Negara Eropa, Jepang, Singapura, Malaysia dan Amerika. Sedangkan Negara pemasok utama di pasaran internasional antara Singapura, Hongkong, Filipina, Selandia Baru, Maldius, India, Srilanka dan Indonesia (Nontji, 2005).

Menurut Anjani et al., 2019 menyatakan bahwa Teripang merupakan salah satu sumberdaya pesisir yang melimpah di perairan Indonesia. Teripang berperan penting sebagai pemakan suspensi (suspension feeder) dan pemakan deposit (deposit feeder). Teripang pada umumnya tinggal pada sedimen berpasir di lingkungan terumbu karang dan lingkungan pantai berlamun. Kedua lingkungan ini apabila keseimbangannya terganggu akibat faktor lingkungan maupun aktivitas artifisial (manusia) maka dapat mempengaruhi kehidupan organisme didalamnya, khususnya kehidupan teripang.

Teripang merupakan biota laut yang bersifat deposit feeder sehingga teripang juga tergolong hewan bentik. Hewan bentik atau biasa disebut bentos sangat bergantung terhadap bahan organik dan renik yang terkandung didalam 
sedimen perairan. Bahan organik yang mengendap di dasar perairan merupakan sumber makanan bagi benthos (Oktamalia et al., 2016).

Menurut Martoyo et al., 2006 menyatakan Teripang gerakannya sangat lambat sehingga hampir seluruh hidupnya berada di dasar laut. Warna tubuh teripang bermacam-macam mulai dari hitam, abu-abu, kecoklat-coklatan, kemerahmerahan, kekuning- kuningan, sampai putih, diantaranya yaitu teripang Pasir (H. scabra) dan Teripang Getah (H. vagabunda). Komposisi dan kebiasaan makan teripang di beberapa wilayah telah dilakukan diantaranya penelitian mengenai kebiasaan makan teripang (Holothuridae) di Pulau Pramuka Kepulauan Seribu Teripang merupakan komponen penting dalam rantai makanan (food chain) terumbu karang dan ekosistem asosiasinya pada berbagai tingkat struktur pakan trophic levels (Agusta et al., 2012),

Teripang berperan penting sebagai pemakan deposit (deposit feeder) yaitu pemakan endapan dan pemakan suspensi (suspensi feeder). Teripang pemakan endapan sangat tergantung kepada kandungan zat organik dalam lumpur, detritus, organik debris, dan plankton. Teripang merupakan pemakan materi tersuspensi yang sangat tergantung pada plankton dan partikelpartikel melayang (seston) (Wulandari et al., 2012). Dari 60 jenis teripang yang ada di Indonesia, 9 jenis yang telah dimanfaatkan sebagai bahan makanan, namun yang banyak digemari ada 2 jenis yaitu teripang pasir (Holothuroidea scabra) dan teripang lotong (Holothuroidea nabilis). Jenis-jenis teripang dimanfaatkan sebagai komoditi eksport antara lain teripang pasir (Holothuroidea scabra), teripang lotong (Holothuroidea nabilis) (Holothuroidea vagabunda) (Kordi, 2011).

Menurut Yusron dan Sjafei (1997), makanan utama teripang dari genus Holothuride adalah plankton dari kelompok diatom. Pemanfaatan sumber daya teripang di Indonesia umumnya dan di Maluku Utara khususnya, sebagian besar masih dititik beratkan pada kegiatan penangkapan di alam. Penangkapan dari alam disatu pihak dapat meningkatkan produksi hasil laut namun dilain pihak dapat mengganggu kelestarian sumber hayati laut, sehingga dikhawatirkan suatu saat akan terjadi kepunahan. Salah satu cara yang dapat ditempuh untuk mencegah terjadi kepunahan tanpa menurunkan hasil produksi yaitu dengan cara budidaya.

Makanan sangat mempengaruhi pertumbuhan organisme di dalam perairan, karna sebagai sumber energi dalam melangsungkan hidupnya. Makanan dapat didefenisikan sebagai segala sesuatu yang biasanya dimakan oleh ikan atau organisme tertentu (Effendi, 2002). Berdasarkan kebiasaan makanan teripang dibagi dalam dua kelompok yakni kelompok pertama adalah jenis pemakan plankton dan pemakan detritus. Jenis teripang pemakan plankton biasanya mendapatkan makananya dengan menggunakan tentakel-tentakel yang berlendir, jenis teripang pemakan plankton yang menjadi makanannya adalah crustacea kecil, protozoa, dan larva-larva ikan lainnya yang ikut menempel pada tentakel mereka (Sutaman, 1993).

\section{Bahan dan Metode}

\section{Waktu dan Tempat}

Penelitian dilaksanakan di Tanjung Gosale Desa Guraping Kecamatan Oba Utara, Kota Tidore Kepulauan Provinsi Maluku Utara, sedangkan waktu pelaksanaan dilakukan pada bulan Oktober 2020.

\section{Prosedur Pengambilan Data}

Pengumpulan data teripang dilakukan pada siang hari saat air laut surut dengan menggunakan tehnik survey jelajah, yaitu dengan berjalan melintasi area penelitian. Jenis teripang yang ditemukan selanjutnya di determinasi berdasarkan petunjuk (Sutaman, 1993; Fecter, (1974); Martoyo et al, (2002), dengan melihat ciri-ciri morfologi seperti warna dan bentuk tubuh. Jumlah sampel yang digunakan sebanyak 30 individu. Sampel yang di temukan masukkan di dalam wadah yang berisi air laut, Selanjutnya sampel diawetkan dengan formalin 10\% untuk dibawa ke Laboratorium Bioekologi Program Studi MSP Fakulatas Perikanan dan Ilmu Kelautan Unkhair Ternate dan Balai Karantina Ikan Kelas II Ternate. Prosedur penelitian terlebih dahulu dilakukan pengukuran panjang dan berat tubuh teripang dengan menggunakan mistar ukur dan timbangan analitik.

Selanjutnya teripang tersebut di bedah untuk diambil lambungnya, kemudian dianalisis makanan yang terdapat dalam lambung. Sebelum 
lambung dibedah terlebih dahulu dilakukan pengukuran panjang total dan panjang lambung dengan menggunakan mistar. Lambung teripang yang sudah di bedah selanjutnya dilakukan pengamatan isi lambung per individu dibawa mikroskop untuk mengetahui jenis-jenis organisme makanan yang terdapat dalam lambung ikan tersebut. Hasil pengamatan pada mikroskop di identifikasikan sesuai petunjuk (Yamaji, 1966).

\section{Metode Frekuensi Kejadian}

Setiap jenis makanan yang terdapat didalam isi lambung dicatat (baik yang kosong maupun yang berisi) dan dianggap sebagai suatu kejadian. Kejadian setiap jenis makanan tersebut dijumlahkan dan dinyatakan dalam persen (\%) dari seluruh sampel, namun tidak meliputi alat pencernaan yang tidak berisi. Dengan demikian kita dapat melihat frekuensi kejadian suatu jenis makanan yang dimakan oleh teripang.

\section{Metode Gravimetrik}

Isi makanan dikeringkan dengan cara meletakkan makanan tersebut di atas kertas saring. Masing-masing jenis makanan dipisahkan dan ditimbang beratnya dengan menggunakan timbangan analitik (ketelitian 0,01 gram). Berat masing-masing jenis makanan dinyatakan dalam persen berat $(\% \mathrm{~W})$ dari seluruh berat teripang tersebut.

Metode analisis laboratorium terdiri dari metode jumlah, metode frekuensi kejadian dan metode gravimetrik mengikuti petunjuk Effendi, 2002 Prosedur metode tersebut sebagai berikut:

\section{Metode Jumlah}

Makanan dalam isi lambung yang telah dipisahkan tiap jenisnya dihitung dan dinyatakan dalam persen dari jumlah total makanan dalam lambung.

\section{Analisis Data}

Hubungan dari jenis makanan yang dimakan dan untuk mendapatkan angka dari masing-masing jenis makanan digunakan indeks relatif penting, penentuan kelompok makanan menggunakan koefisien makanan dengan beberapa ketentuan [8] dan penentuan panjang usus relatif digunakan formula sebagai berikut:

1. Indeks Relatif Penting (IRP)

$$
I R P=\% W \times \% F
$$

Keterangan:

$\% \mathrm{~W}=$ Persentase berat suatu jenis makanan terhadap berat seluruh jenis makanan dalam suatu lambung.

$\% \mathrm{~F} \quad=$ Persentase kejadian suatu jenis makanan terhadap semua jenis yang terdapat dalam suatu lambung.

2. Koefisien Makanan $(\mathrm{Q})$

$$
\mathrm{Q}=\mathrm{Cn} \times \mathrm{Cp}
$$

Keterangan:

a. $\quad C n=\frac{n i}{N p} \times 100 \%$

Keterangan:

$n i=$ total jumlah makanan dalam lambung

$N p=$ jumlah total makanan dalam lambung

b. $\quad C p=\frac{n p}{P p} \times 100 \%$

Keterangan:

$n p=$ Berat makan $\mathrm{i}$

$P p=$ Berat total dalam lambung

Untuk mengetahui pentingnya kelompok makanan tertentu dengan memperhatikan jumlah, berat dan sekaligus frekuensi dari kelompok makanan digunakan koefisien makanan $(\mathrm{Q})$ :

Dengan ketentuan jika:

Q>200 : Adalah makanan utama, makanan ini dianggap sebagai sumber energi utama bagi kebutuhan ikan dan dapat dipakai untuk menentukan makanan yang sebenarnya.

$20<\mathrm{Q}<200$ : Adalah makanan kedua, kelompok makanan ini adalah sebagai makanan tambahan.

$\mathrm{Q}<20$ : Adalah makanan isidental atau kadang kala, kelompok makanan ini tidak mempunyai nilai energi.

3. Panjang Usus Relatif (PUR)

Panjang usus relatif digunakan sebagai data pelengkap untuk menduga kebiasaan makanan pada teripang. Penentuan PUR menggunakan metode Harpher (1998) [9] yaitu :

$$
P U R=\frac{P L}{P B}
$$




$$
\begin{aligned}
& \text { Keterangan : } \\
& \text { PUR = panjang lambung relatif } \\
& \text { PL = panjang lambung }(\mathrm{cm}) \\
& \text { PB }=\text { panjang total }(\mathrm{cm})
\end{aligned}
$$

Ketentuan :

Panjang lambung > Panjang baku $=$ Ikan herbivora dan detritus

Panjang lambung < Panjang baku = Ikan karnivora

Panjang lambung = panjang baku = Ikan omnivore

\section{Hasil dan Pembahasan}

Tanjung Gosale merupakan daerah teluk yang berada dalam wilayah Desa Guraping Kecamatan Oba Utara Kota Tidore Kepulauan Provinsi Maluku Utara. Secara geografis Tanjung Gosale terletak pada posisi $00^{\circ} 46^{\prime} 32,7^{\prime \prime}$ Lintang Utara dan $127^{\circ} 36^{\prime} 02,0^{\prime \prime}$ Bujur Timur, dimana wilayah ini berbatasan dengan Desa Kaiyasa di sebelah Utara, Desa Guraping sebelah Selatan, Hutan sebelah Timur dan Pulau Sibu sebelah Barat. .Perairan Tanjung Gosale memiliki ekosistem pesisir yang terdiri dari ekosistem padang lamun, mangrove dan ekosistem terumbu karang. Perairannya memiliki .zona intertidal dengan bentuk topografi landai dengan jenis substrat heterogen yaitu pasir, pasir berkarang, lumpur dan lumpur berpasir. Potensi sumberdaya perikanan Tanjung Gosale terdiri dari teripang, moluska, rumput laut, ikan dan bulu babi. Sebagian masyarakat nelayan selalu mendatangi tanjung ini untuk menangkap hasil-hasil perikanan tersebut. Pada Tahun 2016 wilayah ini sebagian sudah dijadikan sebagai areal obyek wisata mangrove.

\section{Komposisi dan Deskripsi Jenis Teripang}

Berdasarkan hasil determinasi teripang yang dilakukan dengan melihat ciri-ciri morfologi sesuai petunjuk Martoyo et al, 2002, ditemukan komposisi jenis teripang di lokasi penelitian terdiri dari satu (1) genus yaitu Holothuria dengan 2 jenis yaitu Holothuria scabra dan Holothuria edulis.

\section{a. Holothuria scabra (Teripang pasir)}

$\begin{array}{ll}\text { Phylum } & \text { : Echinodermata } \\ \text { Klas } & \text { : Holothuroidea }\end{array}$

$\begin{array}{ll}\text { Ordo } & : \text { Aspidochirotidae } \\ \text { Famili } & : \text { Holothuroidae } \\ \text { Genus } & : \text { Holothuria } \\ \text { Spesies } & : \text { Holothuria scabra }\end{array}$

Ciri-ciri jenis ini, bentuk badan bulat panjang. Di bagian perut umumnya berwarna kuning keputih-putihan. Punggungnya berwarna abu-abu sampai kehitaman, dengan garis-garis melintang berwarna hitam. Seluruh tubuh bila diraba terasa kasar (Gambar 1).

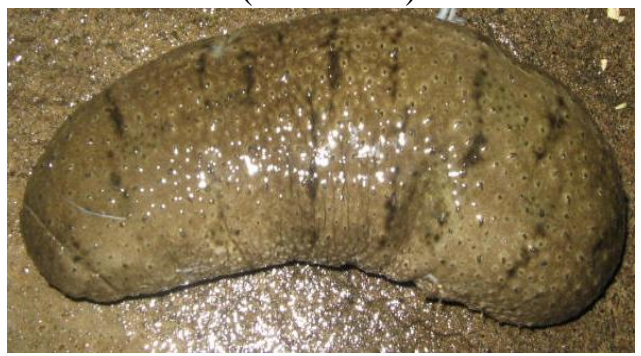

Gambar 1. Holothuria scabra

\section{b. Holothuria edulis (Teripang hitam)}

Phylum: Echinodermata

Klas : Holothuroidea

Ordo : Aspidochirotidae

Famili : Holothuroidae

Genus : Holothuria

Spesies : Holothuria edulis

Ciri-ciri morfologi jenis ini yaitu badan teripang hitam berbentuk bulat panjang. Apabila diangkat dari permukaan air, badannya akan segera mengerut. Di seluruh badannya terdapat bintil-bintil halus. Bagian punggungnya berwarna hitam keungu-unguan atau kebiru-biruan. Sedangkan pada bagian perut, sisi sekitar mulut, dan dubur berwarna kemerah-merahan (Gambar 2).

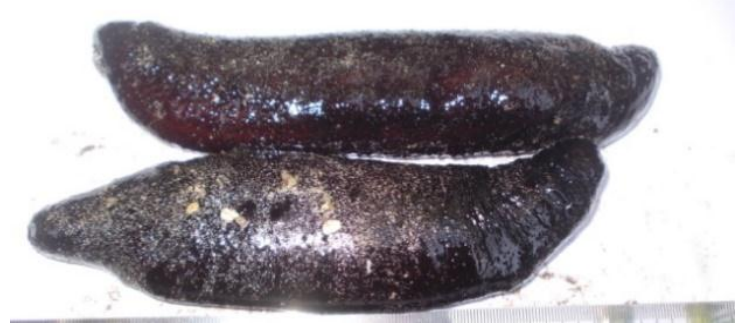

Gambar 2. Holothuria edulis

Komposisi jenis makanan 
Teripang berperan penting sebagai pemakan deposit (deposit feeder) yaitu pemakan endapan dan pemakan suspensi (suspensi feeder). Teripang pemakan endapan sangat tergantung kepada kandungan zat organik dalam lumpur, detritus, organik debris, dan plankton. Teripang merupakan pemakan materi tersuspensi yang sangat tergantung pada plankton dan partikelpartikel melayang (seston) (Wulandari et al., 2012).

Makanan utama teripang genus Holothuridea adalah plankton dari kelompok diatom (Yusron dan Sjafei, 1997).

Makanan yang ditemukan di dalam organ pencernaan teripang tidak dicerna dengan baik sehingga semua jenis makanan yang ditemukan masih dalam keadaan utuh dan masih mudah untuk diidentifikasi. Tidak tercernanya semua makanan dengan baik disebabkan kemampuan teripang dalam menelan yang tidak selektif baik terhadap ukuran granula ataupun kandungan zat organik (Pawson, 1996 dalam Herfin et al., 2019

Elfidasari et al., (2012), makanan teripang berupa plankton, detritus dan kandungan zat-zat organik lainnya yang berada di dalam sedimen lumpur atau pasir. Jenis makanan utama teripang hitam (Holothuria atra) $(>25 \%)$ yaitu Rhizosolenia spp dan jenis makanan yang tidak teridentifikasi. Jenis makanan tambahan teripang hitam (Holothuria atra) (kisaran 4 yaitu butiran pasir dan sisanya sebagai jenis makanan pelengkap. Jenis makanan pelengkap (4\%) yaitu Protoperidinum spp, Ceratium spp, Iasis spp,
Triceratium spp, Nitzschia spp dan Coscinodiscus spp. Selain itu, telah diketahui bahwa teripang selain bersifat deposit feeder juga bersifat poliphagia yang memakan segala sesuatu yang terdapat di dasar (sedimen) perairan seperti detritus, partikel-partikel pasir, hancuran karang, diatomik bentik, alga hijau, alga biru berfilamen yang hidup maupun yang sudah mati di permukaan karang, alga merah, copepoda dan gastropoda (Bakus, 1973).

Hasil penelitian yang dilakukan di Laboratorium Bioekologi Program Studi MSP Fakultas Perikanan Dan Ilmu Kelautan Unkhair Ternate dan Lab. Balai Karantina Ikan II Ternate dengan menggunakan metode jumlah, frekuensi kejadian dan gravimetrik diperoleh komposisi jenis makanan teripang dari 60 individu (30 individu jenis Holothuria scabra dan 30 individu Holothuria edulis), diperoleh komposisi jenis makanan dan secara ringkas disajikan pada tabel 1 dan 2.

Berdasarkan tabel 1 dan 2 tersebut, diperoleh komposisi jenis makanan baik jenis teripang Holothuria scabra maupun Holothuria edulis sebanyak 4 jenis yang terdiri dari alga, lamun, hancuran karang dan pasir. Dari ke empat jenis makanan tersebut, yang memiliki jumlah terbanyak adalah untuk kedua jenis teripang tersebut yaitu pasir dan terendah alga untuk jenis Holothuria scabra dan lamun untuk jeni $H$. Edulis. Sedangkan jenis makanan yang memiliki berat tertinggi adalah pasir dan terendah alga dan lamun.

Tabel 1. Komposisi jenis makanan teripang Holothuria scabra

\begin{tabular}{|c|l|c|c|c|}
\hline No & \multicolumn{1}{|c|}{$\begin{array}{c}\text { Jenis } \\
\text { Makanan }\end{array}$} & $\begin{array}{c}\text { Jumlah } \\
\text { Makanan }\end{array}$ & $\begin{array}{c}\text { Berat } \\
\text { Makanan (gr) }\end{array}$ & $\begin{array}{c}\text { Jumlah Lambung } \\
\text { Berisi Makanan }\end{array}$ \\
\hline 1 & Alga & 35 & 0.226 & 12 \\
\hline 2 & Hancuran karang & 57 & 8.342 & 16 \\
\hline 3 & Lamun & 71 & 0.239 & 21 \\
\hline 4 & Pasir & 14793 & 591.705 & 30 \\
\hline \multicolumn{2}{|c|}{ Jumlah } & 14956 & 600.512 & \\
\hline
\end{tabular}

Tabel 2. Komposisi jenis makanan teripang Holothuria edulis

\begin{tabular}{|c|l|c|c|c|}
\hline No & \multicolumn{1}{|c|}{$\begin{array}{c}\text { Jenis } \\
\text { Makanan }\end{array}$} & $\begin{array}{c}\text { Jumlah } \\
\text { Makanan }\end{array}$ & $\begin{array}{c}\text { Berat } \\
\text { Makanan (gr) }\end{array}$ & $\begin{array}{c}\text { Jumlah Lambung } \\
\text { Berisi Makanan }\end{array}$ \\
\hline 1 & Alga & 31 & 0.190 & 11 \\
\hline 2 & Hancuran karang & 53 & 8.012 & 16 \\
\hline
\end{tabular}




\begin{tabular}{|l|l|c|c|c|}
3 & Lamun & 29 & 0.110 & 29 \\
\hline 4 & Pasir & 15191 & 607.650 & 30 \\
\hline \multicolumn{2}{|c|}{ Jumlah } & 15304 & 615.962 & \\
\hline
\end{tabular}

\section{Frekuensi kejadian dan indeks relatif penting}

Metode frekuensi kejadian dilakukan

untuk mengetahui persentase kejadian suatu jenis makanan. Hasil analisis frekuensi kejadian jenis makanan teripang dapat dilihat pada Gambar 3

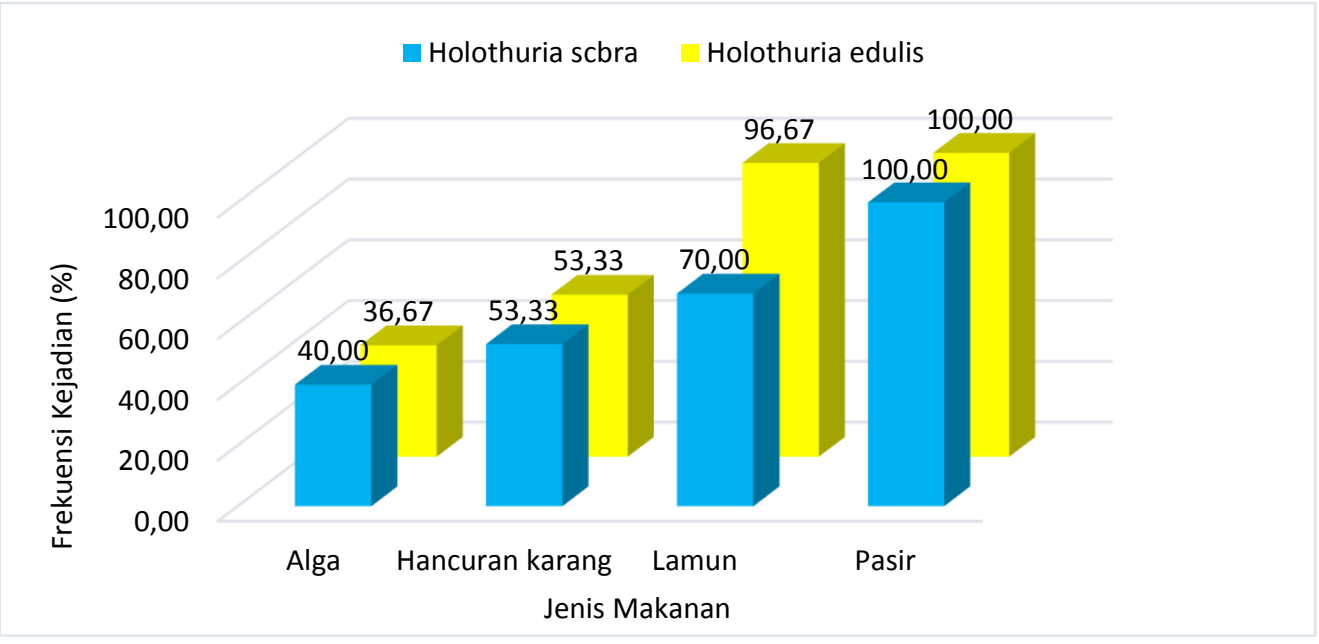

Gambar 3. Frekuensi Kejadian Jenis Makanan Teripang

Berdasarkan Gambar 3 tersebut, menunjukkan bahwa jenis makanan pasir memiliki frekuensi kejadian $100 \%$ baik jenis $H$. scabra maupun $H$. edulis, selanjutnya lamun 96,67\% (H. edulis), 70,00\% (H. scabra), Hancuran karang 53,33\% kedua jenis teripang, sedangkan frekuensi kejadian terendah terdapat pada jenis makanan alga yaitu $36,67 \%$ (H. edulis) dan $40,00 \%$ (H. scabra).
Indeks Relatif Penting (IRP) digunakan untuk menentukan hubungan dari jenis makanan yang dimakan dan untuk mendapatkan angka dari masing-masing jenis makanan yang dimakan Kordi, 2011. Metode Indeks Relatif Penting (IRP) diperoleh dengan menggabungkan persentase berat suatu jenis mamakan dan persentase frekuensi jenis makanan [Romimohtarto,2001]. Hasil analisis Indeks Relatif Penting (IRP) dapat dilihat pada tabel 3 .

Tabel 3. Hasil Analisis Indeks Relatif Penting Jenis Makanan Teripang

\begin{tabular}{|c|l|c|c|}
\hline \multirow{2}{*}{ No. } & \multirow{2}{*}{ Jenis Makanan } & \multicolumn{2}{|c|}{ Jenis Teripang } \\
\cline { 3 - 4 } & & Holothuria scbra & Holothuria edulis \\
\hline 1 & Alga & 1.51 & 1.23 \\
\hline 2 & Hancuran karang & 74.09 & 69.37 \\
\hline 3 & Lamun & 2.79 & 1.25 \\
\hline 4 & Pasir & 9853.35 & 9865.06 \\
\hline
\end{tabular}

Berdasarkan Tabel 3 tersebut, diperoleh jenis makanan yang memiliki Indeks Relatif Penting terbesar adalah pasir yaitu 9853,30 ( $H$. scabra) dan 9865,06 (H. edulis), selanjutnya diikuti oleh hancuran karang dengan IRP $=69,37$
(H. edulis), IRP $=74,09$ (H. scabra) dan lamun dengan IRP $=2,79$ (H. scabra) dan IRP $=1,22(H$. edulis), sedangkan IRP terendah pada jenis makanan alga dengan nilai IRP $=1,53$ ( H. scabra) dan IRP $=1,23$ (H. edulis). 


\section{Koefisien jenis makanan}

Koefisien makanan digunakan untuk menentukan pentingnya kelompok makanan pada teripang.
Analisis koefisien makanan sedangkan hasil analisisnya secara ringkas disajikan pada tabel 4 dan 5 .

Tabel 4. Hasil Analisis Koefisien Makanan Teripang Holothuria scabra

\begin{tabular}{llcccl}
\hline No & $\begin{array}{c}\text { Jenis } \\
\text { Makanan }\end{array}$ & Cn & Cp & Q & Keterangan \\
\hline 1 & Alga & 0.23 & 0.04 & 0.009 & Makanan isidental \\
\hline 2 & Hancuran karang & 0.38 & 1.39 & 0.529 & Makanan isidental \\
\hline 3 & Lamun & 0.47 & 0.04 & 0.019 & Makanan isidental \\
\hline 4 & Pasir & 98.91 & 98.53 & 9745.713 & Makanan Utama \\
\hline
\end{tabular}

Tabel 5. Hasil Analisis Koefisien Makanan Teripang Holothuria edulis

\begin{tabular}{llcccl}
\hline No & \multicolumn{1}{c}{$\begin{array}{c}\text { Jenis } \\
\text { Makanan }\end{array}$} & Cn & Cp & Q & Keterangan \\
\hline 1 & Alga & 0.20 & 0.03 & 0.006 & Makanan isidental \\
\hline 2 & Hancuran karang & 0.35 & 1.30 & 0.450 & Makanan isidental \\
\hline 3 & Lamun & 0.19 & 0.02 & 0.003 & Makanan isidental \\
\hline 4 & Pasir & 99.26 & 98.65 & 9792.377 & Makanan Utama \\
\hline
\end{tabular}

Berdasarkan Tabel 4 dan 5 tersebut, diperoleh kedua jenis teripang memiliki 2 kelompok jenis makanan yaitu makanan utama dan makanan isidental atau kadang kala. Makanan utama teripang Holothuria scabra dan H. edulis terdapat pada jenis makanan pasir, sedangkan makanan isidental atau kadang kala terdapat pada jenis makanan alga, hancuran karang dan lamun. Pasir merupakan makanan utama, hal ini didukung juga dari analisis frekuensi kejadian dan nilai IRP memiliki nilai lebih tinggi.

\section{Panjang usus relatif}

Secara umum teripang dapat dibedakan kedalam kelompok pemakan herbivora dan deposit. Selain susunan kebiasaan makan suatu jenis teripang dapat juga diketahui apakah teripang pasir tergolong herbivora dan deposit dari panjang usus. Analisis panjang usus relatif secara ringkas disajikan pada Gambar 4.

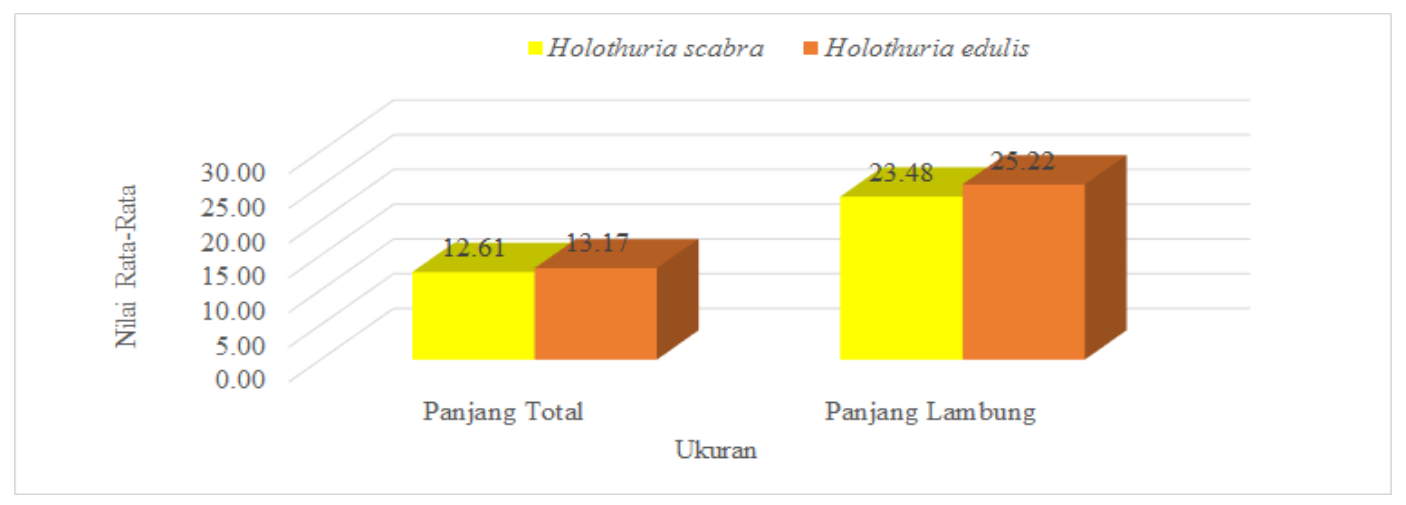

Gambar 4. Hasil analisis rata-rata panjang total dan panjang lambung 
Berdasarkan nilai panjang total untuk Holothuria scabra berkisar antara 8,70 - 14,00 $\mathrm{cm}$ dengan rata-rata $12,61 \mathrm{~cm}$ dan panjang lambung berkisar antara 17,1 - 25,0 $\mathrm{cm}$ dengan rata-rata 23,48. Sedangkan jenis Holothuria edulis diperoleh kisaran panjang 8,3-20,5 cm dengan rata-rata $13,15 \mathrm{~cm}$ dan panjang lambung berkisar antara 15,3 - 30,2 cm dengan rata-rata 25,22. Panjang Usus Relatif (PUR) diperoleh dari hasil perbandingan antara panjang usus dengan panjang total.

\section{Komposisi jenis makanan}

Hasil penelitian yang dilakukan dengan menggunakan metode jumlah, frekuensi kejadian dan gravimetrik diperoleh komposisi jenis makanan baik jenis teripang Holothuria scabra maupun Holothuria edulis sebanyak 4 jenis yang terdiri dari alga, lamun, hancuran karang dan pasir. Dari ke empat jenis makanan tersebut, yang memiliki jumlah terbanyak adalah untuk kedua jenis teripang tersebut yaitu pasir dan terendah alga untuk jenis Holothuria scabra dan lamun untuk jeni $H$. Edulis. Sedangkan jenis makanan yang memiliki berat tertinggi adalah pasir dan terendah alga dan lamun.

Komposisi jenis makanan merupakan susunan jenis-jenis makanan yang terdapat dalam tubuh suatu makhluk hidup. Komposisi jenis makanan yang ada dalam tubuh makhluk hidup tersebut sangat berkaitan dengan kesukaan makan terhadap suatu jenis makanan yang diinginkan. Makanan utama teripang adalah organismeorganisme kecil, detritus (sisa-sisa pembusukan bahan organik), dan diatom. Jenis makanan lainnya adalah radiolaria, foraminifera, partikelpartikel pasir ataupun hancuran-hancuran karang. Martoyo et al, 1994. Menurut Setiawan et al. (2017), hasil pengamatan isi perut teripang pada H. atra, S. maculate, H. impatients, dan P. graffei ditemukan jenis makanan seperti Nitzchia, Thallasiothrix, Coscinodiscus, Pleurosigma, Rhizosolenia, Cocconeis, dan Butiran pasir.

Pasir merupakan jenis makanan yang memiliki berat tertinggi, karena ditemukan disemua individu teripang baik pada jenis Holothuria scabra maupun $H$. edulis, selanjutnya alga pada 12 individu (H.scabra), 11 individu ( $H$. edulis), hancuran karang ditemukan pada 16 individu untuk kedua jenis, lamun ditemukan pada 21 individu (H. scabra), 29 individu $(H$. edulis) dan lamun pada 21 individu (H. scabra) dan 29 individu pada jenis H. edulis.

Umumnya jenis-jenis makanan yang ditemukan tersebut sebagian dalam bentuk hancuran dan sebagian lagi masih. Nampak. Hancurnya jenis-jenis organisme makanan dalam lambung teipang tersebut diduga pada saat pengambilan sampel proses pencernaan mulai berjalan. Mudjiman (2002), menyatakan bahwa semakin banyak makanan dalam isi lambung akan mempengaruhi berat jenis-jenis makanan tersebut. Dengan demikian dapat dikatakan bahwa berat jenis-jenis makanan dalam lambung sangat berkaitan erat dengan kemampuan teripang tersbut dalam mendapatkan jenis makanan yang tersedia.

\section{Frekuensi kejadian dan indeks relatif penting}

Metode frekuensi kejadian dilakukan untuk mengetahui persentase kejadian suatu jenis makanan. Hasil penelitian menunjukkan bahwa jenis makanan pasir memiliki frekuensi kejadian $100 \%$ baik jenis $H$. scabra maupun $H$. edulis, selanjutnya lamun $96,67 \%$ (H. edulis), 70,00\% (H. scabra), Hancuran karang 53,33\% kedua jenis teripang, sedangkan frekuensi kejadian terendah terdapat pada jenis makanan alga yaitu 36,67\% (H. edulis) dan 40,00\% (H. scabra).

Kebiasaan makan Teripang Pasir $(\mathrm{H}$. scabra) dan Teripang Getah (H. vagabunda) yaitu kelas Bacillariophyceae dengan persentase IP tertinggi sebesar $49,82 \%$ dan $50,75 \%$ menunjukkan bahwa Bacillariophyceae merupakan makanan utama (Dini et al, 2020)

Frekuensi kejadian dilakukan dengan melihat komposisi jenis makanan, lambung yang berisi makanan dan yang tidak berisi makanan. Perbandingan banyaknya lambung yang berisi makanan dan jumlah total lambung disebut dengan frekuensi kejadian suatu jenis makanan [Effendie, 2002]. Berdasarkan hasil analisis maka diperoleh makanan pasir memiliki nilai frekuensi kejadian lebih tinggi yaitu $100 \%$, karena semua lambung yang di bedah (30 lambung) terdapat makanan pasir, sedangkan jenis makanan alga hanya terdapat pada 12 dan 11 lambung sehingga memiliki nilai frekuensi kejadian lebih rendah.

Indeks Relatif Penting (IRP) digunakan untuk menentukan hubungan dari jenis makanan yang dimakan dan untuk mendapatkan angka dari masing-masing jenis makanan yang dimakan [kordi, 2011. Metode Indeks Relatif Penting 
(IRP) diperoleh dengan menggabungkan persentase berat suatu jenis mamakan dan persentase frekuensi jenis makanan (Romimohtarto, 2001). Makanan jenis pasir memiliki nilai IRP lebih tinggi, karena jenis makanan ini memiliki persentase kejadian dan persentase berat lebih tinggi bilan dibandingkan dengan jenis makanan lainnya yang terdapat dalam lambung teripang. Hal ini mengindikasikan bahwa pasir merupakan jenis makanan yang paling disukai oleh teripang karena mengandung bahan organik.

\section{Koefisien jenis makanan}

Koefisien makanan digunakan untuk menentukan pentingnya kelompok makanan pada teripang. Hasil analisis diperoleh kedua jenis teripang memiliki 2 kelompok jenis makanan yaitu makanan utama dan makanan isidental atau kadang kala. Makanan utama teripang Holothuria scabra dan H. edulis terdapat pada jenis makanan pasir, sedangkan makanan isidental atau kadang kala terdapat pada jenis makanan alga, hancuran karang dan lamun. Pasir merupakan makanan utama, hal ini didukung juga dari analisis frekuensi kejadian dan nilai IRP memiliki nilai lebih tinggi. [Romimohtarto, 2001] bahwa untuk mengetahui pentingnya kelompok makanan tertentu dengan memperhatikan jumlah, berat dan sekaligus frekuensi dari kelompok makanan. Lebih lanjut dikatakan bahwa kelompok makanan yang disukai organisme terdiri dari makanan utama, makanan kedua atau tambahan dan makanan insidentil. Makanan utama merupakan makanan yang dianggap sebagai sumber energi utama dan di pakai untuk menentukan makanan yang sebenarnya. Makanan kedua merupakan kelompok makanan tambahan, sedangkan kelompok makanan insidentil atau kadang kala, merupakan kelompok makanan yang tidak mempunyai nilai energi. Lebih lanjut dikatakan bahwa apabila nilai koefisien makanan (Q) $>200$ adalah makanan utama dan $20<\mathrm{Q}<200$ adalah makanan kedua atau makanan tambahan.

Pasir merupakan makanan utama dari teripang pasir. Hal ini dapat dikatakan bahwa teripang pasir merupakan jenis teripang yang memiliki kebiasaan makanan bersifat deposit feeder. Hal ini diperkuat oleh pernyataan), bahwa pada umumnya teripang adalah pemakan deposit pasir yang penting di daerah coral reef. Sedangkan sumber utama makanannya adalah plankton, potongan serasah karang atau detritus yang terdapat dalam lumpur. Selain itu teripang juga memakan Foraminifera, Radiolaria dan cangkang-cangkang hewan lainnya. Lebih lanjut [3], bahwa untuk makanan deposit, teripang menelan pasir dalam jumlah banyak untuk mendapatkan bahan organik yang cukup untuk dicerna kemudian pasir dikeluarkan melalui anus. sumber utama makanan teripang di alam yaitu kandungan zat organik dalam lumpur, detritus dan plankton. Selain itu juga memakan potonganpotongan hewan kecil maupun tumbuhan laut. [Effendi,2002)

\section{Panjang usus relatif}

Secara umum teripang dapat dibedakan kedalam kelompok pemakan herbivora dan deposit. Selain susunan kebiasaan makan suatu jenis teripang dapat juga diketahui apakah teripang pasir tergolong herbivora dan deposit dari panjang usus. Hasil analisis diperoleh ratarata panjang total Holothuria scabra yaitu 12,61 $\mathrm{cm}$ dan rata-rata panjang lambung $23,48 \mathrm{~cm}$. Sedangkan jenis Holothuria edulis diperoleh ratarata panjang total $13,15 \mathrm{~cm}$ dan rata-rata panjang lambung 25,22 cm. Ini menunjukkan bahwa panjang lambung lebih panjang dari panjang total teripang. Panjang Usus Relatif (PUR) diperoleh dari hasil perbandingan antara panjang usus dengan panjang total. [Martoyo,et al 1994], menyatakan pencernaan organisme buas lebih pendek dari saluran pencernaan organisme vegetaris, dimana pada organisme buas saluran pencernaan hanya sepanjang tubuhnya saja, sedangkan pada organisme vegetaris atau deposit dapat mencapai tiga kali lebih panjang dari tubuhnya.

Berdasarkan hal tersebut, bila dihubungkan dengan hasil penelitian ini, dimana hasil pengukuran diperoleh panjang lambung lebih panjang dari panjang total, maka dapat dikatakan bahwa kedua jenis teripang digolongkan pemakan deposit dan herbivora. Hal ini dapat dibuktikan juga dari komposisi jenis makanan yang diperoleh, yaitu pasir, alga dan lamun.

\section{Kesimpulan}

Berdasarkan hasil penelitian, maka dapat dikemukakan kesimpulan sebagai berikut Komposisi jenis makanan teripang Holothuria scabra dan Holothuria edulis terdiri dari alga, hancuran karang, lamun dan pasir dan Koefisien 
makanan yang diperoleh menunjukkan ada 2 kelompok makanan yaitu makanan utama dan insidental atau kadang kala. Kelompok makanan utama yaitu pasir dan isedental atau kadang kala yaitu alga, hancuran karang dan lamun.

\section{Ucapan Terima Kasih}

Terima kasih kepada seluruh Masyarakat sekitar Tanjung Gosale Oba Utara dan pihak yang telah berkontribusi secara langsung maupun tidak langsung dalam penelitian ini.

\section{References}

Aziz, A. (1996). Makan dan Cara Makan Berbagai Jenis Teripang. Oseana, Volume XXI, Nomor 4, 1996: 43 - 59.

Agusta O. Ruzfi, Bambang S \& Siti Rudiyanti. (2012). Kebiasaan Makan Teripang (Echinodermata: Holothuriidea) Di Perairan Pantai Pulau Pamuka, Kepulauan Seribu. Journal of Management of Aquatic Resource.Hal 1-8.

Bakus, G.J. (1973). The Biology and Ecology of Tropical Holothurian. In O.A. Jones and R. Endean (Eds) Geology and Biology of Coral Reefs.

Dini Deskarosa Rahma, Susiana Susiana \& Ani Suryanti. (2020). Kebiasaan Makan Teripang Pasir (Holothuria scabra) dan Teripang getah (Holothuria vagabunda) Di Perairan Karas, Kota Batam, Indonesia. Jurnal Akuakultur, Pesisir dan Pulau-pulau Kecil. 4(1), 13-19.

Elfidasari D, Nita Noriko, Ninditasya wulandari \& Analekta Tiara Perdana. (2012). Identifikasi jenis Teripang Genus Holothuria asal Perairan sekitar Kepulauan Seribu berdasarkan perbedaan morfologi. Jurnal Al-azhar Indonesia seri sains dan Teknologi, 1 (3), 140-146.

Effendie, M. I. (2002). Metode Biologi Perikanan. Yayasan Dewi Sri. Bogor.

Fecter, H. (1974). The Sea Cucumbers in Gramica Animal Like Encyclopedia Vol.
III. Mollusca Echinoderms. Van Houstrand Reinhold Company. New York.

Herfin, A. Hamid \& Haslianti. (2019). Studi Kebiasaan Makan Teripang Pasir (Holothuria scabra) di Perairan Desa Alosi Kecamatan Kolono Kabupaten Konawe Selatan. Jurnal Manajemen Sumber Daya Perairan. 4 (1): 15

Handayani tutik, Vera sabariah \& Ronald R. Hambuako. (2017). Komposisi Spesies Teripang (Holothureidea) Di Perairan Kampung Kapisawar Distrik Meos Manswar Kabupaten Raja Ampat. Jurnal Perikanan. UGM, 19 (1), 45-51.

Kordi, M. G. H. (2011). Ekosistem Padang Lamun (Seagrass) Fungsi, Potensi, Pengelolaan. Penerbit Rineka Cipta

Mujiman A. (2000). Makanan Ikan. Penebar Swadaya. Jakarta.

Martoyo, S. M. (2006). Budidaya Teripang. Penebar Swadaya Jakarta.

Martoyo J, Aji N, \& Winanto T. (1994). Budidaya Teripang. Penebar Swadaya. Jakarta. 72 hlm. Martoyo, J. Aji, N. dan Winanto T. (2002). Budidaya Teripang. Penebar Swadaya Jakarta

Martoyo, J., A. Nugroho \& T. Winanto. (2007). Seri Agribisnis: Budidaya Teripang. Penebar Swadaya. Jakarta.

Nontji, A. (2005). Laut Nusantara. Penerbit Djambatan. Jakarta.

Romimohtarto, K \& Juana, S. (2001). Biologi laut. Pengetahuan Tentang Biota Laut. Djambatan.

Setiawan, B.P., Suryanti \& Sulardiono, B. (2017). Preferensi Habitat dan Kebiasaan Makan Teripang (Holothuroidae) di Perairan Pulau Menjangan Kecil, Karimunjawa, Jepara. Journal of Maquares. 6(4): 401-408 
Setyastuti Ana (2015). Sinopsis Teripang Indonesia Dulu, Sekarang dan Yang Akan Datang. Jurnal Oseana, XI (3), 1-10.

Sutaman (1993). Petunjuk Praktis Budidaya Teripang. Kanisius. Yogyakarta.

Wulandari, N., M. Krisanti \& D. Elfidasari (2012). Keragaman teripang asal pulau pramuka kepulauan ser. J. Unnes of Life Science Universitas Negeri Semarang. 2: 1.

Yamaji (1966). Ilustrations Of The Plankton. University of Haikusa. Japan.

Yusron, E \& Sjafei, S. D. (1997). Studi Analisis Makanan Dari Beberapa Jenis Teripang (Holothuroidea) Di Perairan Pulau Ambon. Institut Pertanian Bogor. Bogor 